\title{
Legal Protection of Daily Freelance Labors in Small- Scale Industry: A Study on Wig and Fake Eyelashes Industries in Indonesia
}

\author{
Susilo Wardani \\ Faculty of Law, Muhammadiyah University Purwokerto
}

\begin{abstract}
The implications of economic and investment globalization have led to the development of wig and fake eyelashes industries in Purbalingga, a small town in Indonesia, which resulted in open work including freelance workers. This fenomena appear from a partnership or subcontracting relationship between large and small industries. In order to meet the needs of the large industries, the small industries, locally referred as plasma industry, then hire daily labors. A legal protection for this type of labors means finding out their rights after carrying out their tasks. Nevertheless, the rights of the daily workers are usually beyond the employers' concern. The working contract is not written and is more like familial relation. This can be seen from the form of legal execution, the contract, the wages, and others. This is due to the lack of legality in the business itself. It is important to note that the government has not made any effort to provide an integrated socialization regarding this matter and the labors do not aware of their own rights. In fact, in the implementation of the legal provisions of daily workers should comply the labor regulations, for example Law Number 13 in 2003 and its implementation.
\end{abstract}

Keywords: Legal Protection \& Freelance Labors

\section{INTRODUCTION}

In today's era, globalization is more likely supported by the proliferation of capitalists that led to economic interdependence; lots of industrial relocationsare done from developed to developing countries. One of the examples is the emergence of many Foreign Capital Companies in Purbalinggawhich focus on hair industry.

Eventhough Purbalingga is just smallregency, but its wig and false eyelashesindustry are the second largest industry in the world after Guangzhou China. The everincreasing quantity of production provides an opportunity for the population to participate in a workforce, resulting in new emerging industrial plasmas that serve as the support of production in the parent industry (PMA). There are two kinds of plasma workers: those of branches and collectors among of whom are freelance plasma workers.

According to an official in Labor Inspector and Civil Service Investigator of the Purbalingga District Labor Office, the coordinator of the plasma workers is 259 people and the number of the workers is 8,587 people. They still get less attention from the government and havenot been fulfilled their rights in accordance with the provisions of applicable legislation. Instead of understanding their own rights and obligation, they rather just do what the industry wants. Owing tosuchissues, this study will focus on how to provide the legal protection of casual workers in small industries, especially in hair and fake eyelashes industries in Purbalingga, Indonesia.

\section{METHOD}

The approach method used in this research is a normative juridical approach method, which means the research will focus on the application of norms or norms in positive law $^{\mathrm{i}}$, how it is applied to a new problem which has no ruling. It was done by determining and compiling the rulings as the research object. The data used are secondary and primary datacollected from library research and from interviews, respectively, as the key information.

\section{RESULT AND DISCUSSION}

The development of the fake eyelashes industrial plasmas has reached into the villages in Purbalingga and its surrounding areas. They hirewoman villagers who have no much choice to earnmoney ${ }^{\text {ii }}$. Daily or casual laborers are the workers / laborers who were tied up with employment relations from day to day and receive wage receipts in accordance with the number of working days or working hours or many items or types of work provided. They do not have the same rights as permanent workers. According to Suryaningrat ${ }^{\mathrm{iii}}$ in general there are symptoms that industrial workers are concentrated on the lowest wages and status position.

Based on my survey, there are workers in the plasmaimplementa system of piecework contract and others work as daily workers. It is unfortunate for them for not screened by their education and age. These are the influences of social condition of the society that from a long time saying they have a low education and wages. They also suffer a deteriorating vision, especially among the female workers.

Based on the study by Abidah and Wardani, ${ }^{\text {iv }}$ and Ragil Utami, vit is revealed that the plasma workers have to work 8 hours from 7.30 to 15.30 , not to mention, they usually bring their target-based job to home. It is also urgent to know that their salary is determined by their presence and the number of piecework they make in a day and get no healthy insurance because they are only freelance labors. Due to the working contract is only a spoken agreement, it has undeniably negative 
consequences to those in a low-level position. It is possible that the workers receive their rights in the legal protection as a worker. ${ }^{\text {vi }}$ As stated on the Article 51 no (1) of the Law No 13 Year 2003 and the Article 12 Ministry Decision No.100 Year 2004, about principle a working contract is made in written. This situation lead nowhere but difficulty for both sides since it leads into a legal uncertainty. Furthermore, the workers are not members of any labor organization which can represent their voices. The life of the worker is a manifestation of a primitive law. ${ }^{\text {vii }}$ Sandra Fredman ${ }^{\text {viii }}$ argues that female workers who work as casual workers (non-standard) have the following characteristics:

Precarious workforce, characterised by low pay, low status and little job security. Nor is it an accident that the precarious workforce is made up predominantly of women. Women are now both homeworkers and breadwinners, constantly traversing the boundary between unpaid and paid work. Yet the change in women's role has not been matched by changing the basic assumptions in labour law that 'work' encompasses paid work only, and that employers' social responsibility only arises as a quid pro quo for the worker's full commitment to the individual employing enterprise. It is argued here that employment rights need to be divorced from the individual employment relationship. Rights should be afforded to all who participate in the paid workforce, however marginally.

In Indonesian law, the rights of casual laborers is equal to the workers under the Working Agreement of Certain Time (PKWT), under which they has the rights of earned wages and welfare. The Provisions of the Working Agreement on Certain Time, namely Article 10 of the Ministerial Decree Number 100 Year 2004, states that casual workers are intended for certain jobs which vary in terms of time and workload and wages based on their attendance. However,Freelance Employment Agreement excludes some general provisions of the PKWT, in which in the Daily Work Agreement contains several conditions including:

1. The Daily Employment Agreement is exercised for certain jobs that vary in time and volume of work and wages based on attendance;

2. A free daily employment agreement is made on the condition that the worker / laborer works less than 21 (twenty one) days in 1 (one) month;

3. In the case of a worker / laborer working 21 (twenty one) days or more for 3 (three) months consecutively or more then the daily work contract is released into PKWTT.

Based on pre-survey and interview with the official of the Social, Labour, and Transmigration Office of the regency, it is known that those who work outside the company, like in the plasma hair industry (small industry) managed by collectors, are hired by wage system or work as freelance workers. Their job is only limited to an assembling of raw materials (hair) to the yarn which is a semi-finished industrial goods.

The activities in the job also have adverse effects to their sights; those who have worked more than half a year mostly will have a decreased eye health. Another effect is an increase of divorce rate, triggered by the extended time they should spent daily in the job because of the wage system. The existence of law in society is a means to create peace of society. ${ }^{\mathrm{i}}$ In practice, the law protection provided for these people is still lacking.

The legal protection of casual laborers in the hair industry, according to an authority of the Supervisory Office of Manpower Office of Purbalingga Regency, is said to be beyond their reach. He said that "plasma workers are not labor and not under the supervision of the Manpower Office". In fact, in the Act No. 13 of 2003 on Manpower, Article 1 paragraph (2) it is clearly mentioned that what is meant by manpower is any person who is capable of doing work to produce goods and/or services either to meet the needs of themselves or for the community. Whereas in paragraph (3) it is explained that the worker/laborer is any person who works by receiving wages or other forms of remuneration. Thus, casual laborers are obviously the workers who produce goods/services to meet the needs of themselves or others and to earn wages or rewards.

The rights of casual workers are actually mentioned in the Journal of Labor and Employment Law $^{x}$ :casual workers do not receive paid vacation, holydays, or sick leave and employer's pension and health insurance plans do not usually include them. These only serve as a safeguard against sub minimum standards.

The relation of daily labors and their employer is usually a colleague under an unwritten agreement. This type of contract can certainly be detrimental to those who have low positions, as it may happen that workers do not get their rights in legal protection as workers ${ }^{\mathrm{xi}}$.

According to the provisions of Article 51 Paragraph (1) of Law Number 13 Year 2003, in principle the employment agreement is made in writing, but considering the conditions of various communities, the agreement may be made orally. Such conditions then create difficulties for both labors and employers; it does not guarantee a legal certainty. Moreover, the casual worker does not have any worker union organization that can channel their aspirations. Their poor situation is exactly like a manifestation of primitive law ${ }^{x i i}$.

Furthermore, the rights to obtain social security for all workers / laborers including the casual laborers have been stipulated in Act Number 24 of 2011 concerning the Social Security Administering Body,in which it is mentioned in Article 15 that "The employer shall step by step register himself and his employees as a participant to BPJS in accordance with the Social Security program that it follows. If an employer other than a state does not enforce this provision, it shall be liable to administrative sanctions as referred to in Article 17 paragraph (2) of Act Number 24 of 2011 concerning the Social Security Administering Body; the sanction 
may be written warning, fine; and/or are not provided with certain public services.

\section{CONCLUSION}

It is clear that the development of small industries like wigs and false eyelashes is to meet the needs of large industries that produce wigs and false eyelashes. These big companiesare mostly Korean investors, under which the industrial plasmas in Purbalingga hire permanent workers and casual workers. Legal protection is the rights for all people including the casual workers in the small industrial plasma, as it is clearly mentioned on Law No. 13 of 2003 on Employment. The oral agreement which is used to be applied in hiring the casual workers is an obvious offence to the working rules. Such a contract makes it hard for the workers to get their legal rights. Meanwhile it is clear that the hiring of casual workers has been regulated by KEPMEN No. 100 of 2004 , in which it is mentioned that they are part of the PKWT and their work agreements shall be made in a written form.

\section{REFERENCES}

[1] Soemardjono, Maria S.W, Pedoman Pembuatan Usulan Penelitian sebuah Panduan Dasar. PT Gramedia Pustaka Utama: Jakarta. hal 40. 1997.

[2] S.Suryaningrat. Perjuangan Wanita Indonesia 10 Windu Setelah Kartini1904-1984. Jakarta: PT. Gita Karya, hal 362-363. 1984.

[3] Abidah Sufi dan Wardani, Susilo.Perlindungan Hukum Terhadap Pekerja Harian Lepas pada Plasma Industri Rambut di UD Rafi Ridho Purbalingga, Fakultas Hukum Universitas Muhammadiyah Purwokerto. 2017.
[4] Utami, Ragil.Perempuan Plasma Industri Bulu Mata Palsu di Desa Tegalpingen Kecamatan Pengadegan Kabupaten Purbalingga Provinsi Jawa Tengah. Fakultas Ilmu Sosial Universitas Negeri Yogyakarta. 2014.

[5] Ahad Abdul, Mahendra Rikki. Kurnia Putra, Susanti Erna, Tinjauan Hukum Terhadap Pelaksanaan Perlindungan Hukum Terhadap tenaga Kerja Harian Lepas (Studi Pada CV Dwijaya Bhakti Kabupaten Penajam Paser Utara, http://e-journal.fhunmul. ac.id/index.php/beraja Volume 3 Nomor 2 (2014) . 2014.

[6] Pratiwi. Fitria dan Lis Sutinah. Rights and Obligations of Contract Workers (eds) Jakarta: PT Visimedia Pustaka page 82. 2016.

[7] Fredman, Sandra. Women at Work: The Broken Promise of FlexicurityIndustrial Law Journal, Volume 33, Issue 4, hal 299, 1 December 2004.

[8] Mertokusumo.Sudikno. Know the Law (An Introduction) Yogyakarta: Liberty. page 39/ 2003.

[9] H.Andrea Brustain U. Casual Workers and Employee Benefits: Staying Ahead of The Curve, PA Journal of Labor and Employment Law Vol.7: 3 hal 697-698. 2005.

[10] Abdul Ahad Riki,Mahendra Putra Kurnia, Erna Susanti. Legal Review Against the Implementation of Legal Protection of Daily Workforce (Study At CV Dwijaya Bhakti Kabupaten Penajam Paser Utara, http://e-journal.fhunmul.ac.id/ index.php/ beraja Volume 3 Nomor 2 (2014). 2014.

[11] Lasswel dalam T.O Ihromi. Antropology and Law, Jakarta: Yayasan Obor Indonesia hal.80. 2010. 